\title{
A Research on Chang Chien's Thought on Local Self-Government
}

\author{
Shun-Chih Sun \\ Department of Translation and Interpretation Studies, Chang Jung Christian University, Tainan, Chinese Taipei \\ Email: scsun16@hotmail.com
}

Received 19 February 2015; accepted 6 March 2015; published 10 March 2015

Copyright (c) 2015 by author and OALib.

This work is licensed under the Creative Commons Attribution International License (CC BY). http://creativecommons.org/licenses/by/4.0/

(c) () Open Access

\begin{abstract}
Chang Chien (1853-1926) was a native of Nant'ung, Kiangsu. In spite of the various works on Chang Chien, which testify to the significance of his role in modern China, Chang Chien's thought on local self-government is still not well-researched. The purposes of this paper are firstly, to analyze Chang Chien's thought on local self-government systematically and clearly in the hope that it may become a useful reference for researchers on modern China, and secondly, to stimulate scholars for further research. This paper depends more on basic source materials rather than secondhand data. Among various source materials, Chang Chien's Diary, The Nine Records of Chang Chien and The Complete Work of Chang Chien are the most important. Chang Chien's thought on local self-government may be summarized as follows: 1) Local self-government under gentry in promoting industry, education and other local affairs as a means of saving China; 2) Local government as basis of the constitutional monarchy; 3 ) Local self-government as basis of the republic. The paper has also discussed the background to Chang Chien's thought on local self-government, the factors which shaped it, how it developed, and its long-term impact.
\end{abstract}

\section{Keywords}

Constitutional Monarchy, Local Self-Government, Education, Industry

Subject Areas: History, Politics

\section{Introduction}

\subsection{Review on the Research Outcome on Chang Chien and the Purposes of This Paper}

So far lots of scholars have done research on this topic; however, the answers to this question have not been completely discovered yet. Chang Hsiao-jo's Biography of Mr. Chang Chien of Nant'ung is a pioneer work which contains a great many source materials on this topic, however, this book suffers from loose organization and superficial treatment of Chang Chien's thought on local self-government [1]. Sung Hsi-Shang's The Career 
of Chang Chien is less a biography than an annotated collection of source materials, drawn largely from Chang Chien's works, supplemented by personal remembrances, but touches little on Chang Chien's thought on local self-government [2]. Liu Hou-sheng's Biography of Chang Chien concentrates on the political events of Chang Chien's time including Chang Chien's thought on local self-government [3]. Samuel C. Chu's Reformer in Modern China: Chang Chien, 1853-1926 emphasizes Chang Chien's role in industry, education, land reclamation, water conservancy and his involvement in national affairs including Chang Chien's thought on local selfgovernment [4]. Chang K'ai-yuan's Biography of Chang Chien discusses Chang Chien's career, political activities and Chang Chien's thought on local self-government [5]. Wang Tung-ch'in's Tradition and Perspective: A Research On Chang Chien's Economic Thought discusses Chang Chien's economic thought in detail including local self-government [6]. Other works by Wong King-kong [7], Lee, Mabel [8], Chang P'eng-yuan [9], Koll, Elisabeth [10], Sun, Shun-chih [11] [12] also give interpretation to Chang Chien's thought on local self-government.

The fourth international symposium on Chang Chien held in Nant'ung on the 25th-28th of November 2006, 88 articles in relation to Chang Chien and modern Chinese society had been submitted to this symposium [13], and the fifth international symposium on Chang Chien held in Haimen on the 17th-19th of April 2009, 120 articles in relation to Chang Chien and Haimen: The Thoughts and Practice in the Early Period of Modernization had been submitted to this symposium [14], however, Chang Chien's thought on local self-government still has not been fully explored yet. The purposes of this paper are firstly, to analyze Chang Chien's thought on local self-governments systematically and clearly in the hope that it may become a useful reference for researchers on modern China, and secondly, to stimulate scholars for further research.

\subsection{Basic Materials}

This paper depends more on basic source materials rather than second-hand data. Among various source materials, Chang Chien's Diary [15] (hereafter cited as Jih-chi) is the most basic one, which covers almost 53 years from 24 October, 1873, when he was twenty years three months and twenty three days, to 2 August, 1926, twenty two days before his death.

This diary contains approximately 875,000 words by which we are able to understand the life of a typical Chinese intellectual, to check the exact dates of some writings of his, and to correct errors against related sources. The first part of Chang Chien's diary which covers approximately the period from 1873 to 1892 was published in Taipei in 1967; and the second part of Chang Chien's diary which covers approximately the period from 1892 to 1926 was later published in Taipei in 1969. These two parts of Chang Chien's diary were reprinted together in 1986 in Taipei covering the period from 1873 to 1926. The Nine Records of Chang Chien [16] (Hereafter cited as Chiu-lu) is an indispensable source material to Chang Chien's thoughts and activities. This collection of his writings is divided topically into: Cheng Wen Lu (On Politics), Shih Yeh Lu (On Industry), Chiao Yu Lu (On Education), Tzu Chih Lu (On Self-government), Tz'u Shang Lu (On Philanthropy), Wen Lu (Essays), Shih Lu (Poems), Chuan Lu (Special Section), and Wai Lu (On the Civil Service Examination). Within each topical section the sources are arranged in Chronological order. The Complete Work of Chang Chien [17] [18], and Extant Writings of Chang Chien [19], include some new data not found in The Nine Records of Chang Chien, are invaluable source materials to Chang Chien's thoughts and activities.

\section{Early Life and the Development of Chang Chien's Thought on Local Self-Government}

Chang Chien (1853-1926), tzu (courtesy title) Chi-chih, hao (alias) Se-an, and Se-Weng, was born the fourth of five sons, on July 1st, 1853 in the village of Ch'ang-lo, Hai-men, Kiangsu, China, and died on August 24th, 1926 in Nant'ung, Kiangsu, China. Chang Chien began his student days in 1856 at the age of only four. His first teacher was his father Chang, P'eng-nien, who taught him to read Book of a Thousand Characters. The following year, 1857, Chang Chien was sent to a village school. The teacher was Ch'iu, Ta-chang, under whom Chang Chien in a period of seven years (1857-1863), had finished the primers such as Trimetric Classics, and Books of Family Names; the basic poetic readers such as Works of A Thousand Poets, and Poems of A Boy Prodigy; and the Confucian Classics such as The Great Learning, The Doctrine of Golden Means, The Analects of Confucius, Mencius, The Filial Piety Classic, and The Book of Odes.

In 1864, his father employed Sung, Hsiao-ch'i as family teacher to help Chang Chien and his brothers in the 
preparation for local examinations. The teacher asked Chang Chien to study again The Great Learning, The Doctrine of Golden Means, The Analects of Confucius, and Mencius, but from better editions. Then he proceeded to teach the boy The Book of History, The Book of Change, The Book of Rites, and T'so's Commentary of the Spring and Autumn Annals. Under his teacher's effective guidance, Chang Chien learned to write examination poems and examination essays which were required in the examinations. Unfortunately, this enthusiastic teacher died in the summer of 1866, and Chang Chien was sent to follow Sung Lin, the dead teacher's nephew, in a neighboring village, HsiT'ing. Under the new teacher, Chang Chien advanced to study two more Confucian classics, The Rite of Chou and The Book of Ritual [16] (Chiu-lu, Chuan Lu, chuan 6, 2a-4b).

Chang Chien's examination life was a long and toilsome history. In the first stage, Chang Chien spent only five years, 1864-1868, in preparation, successfully passed through the district, prefectural, and Yuan (one conducted by provincial literary examiners) examinations, placing twenty-sixth in the latter, and was classified a Fu-sheng (Licentiate) in 1868, at the age of sixteen [1].

The second stage Chang Chien spent seventeen more years, 1869-1885, failed five times in the provincial examinations. The degree of Chiu-jen continued to elude him until 1885, when he competed in the provincial examination and succeeded in placing second highest among who passed.

Chang Chien spent nine more years, 1886-1894, in preparation, failed repeatedly four times in the examinations for Chih-shih degree in Peking in 1886, 1889, 1890, and 1892. In 1894, at the age of 42, Chang Chien, at the insistence of his elder brother, Chang Ch'a, and the encouragement of his aged father, once more took the metropolitan examination. This time, his name was found in the sixtieth position. He improved on this in the re-examination by placing tenth, and when the palace examination was over, he was chosen to be Chuan-yuan, the highest of all.

He was duly appointed a Compiler of the First Class in the Hanlin Academy. Unfortunately, only six months after he had won the highest title of Chuan-yuan, he lost his father, who had played the most important role in his examination life. Four years later, in 1898, when he had decided to take no office in the government and when he was busy promoting local development in his home area, Chang Chien did not forget to come back to Peking for his last examination in Hanlin Academy.

Through the traditional training, Chang Chien had accepted the pragmatic and the reciprocal aspects of Confucianism which later functioned as his guiding spirit in promoting industry, education and self-government as the foundation of a constitutional monarchy, and then a republic.

Before 1895, Chang Chien mainly spent his time in preparing civil service examinations, the ladder of success in the imperial China, and hence he expressed no idea of local self-government at this stage. During the period from 1895 to 1900, he had the idea of mutual assistance of industry and education, but he still had no idea of local self-government yet.

The origins of Chang Chien's ideas on local self-government can be traced back to his Pien-faP'ing-I (Reasoned discussion on Reforms) in 1901 which he suggested Japanese system that local assemblies on the prefectural and district level should be established with suitable members elected exclusively from among the rich and the educated. They would serve four-year terms, with elections for half the total membership every two years. No salaries, but traveling expenses would be paid. As for the functions of local assemblies, Chang Chien suggested the following: deliberation and resolution on the local government affairs, budget, and resolution on details of local taxation. All meetings, Chang Chien emphasized, should be open to the public. He concluded optimistically that the establishment of the local assemblies and the participation of the gentry in local public affairs would surely contribute to the enlightenment of the people, to the success of various reforms such as schools and economic enterprises, and to a communication of minds between the rulers and the ruled. He tactfully point out that the Japanese local assemblies as a matter of fact, originated from the institution of the ancient Chou Dynasty of China [16] (Chiu-lu, Cheng Wen Lu, chuan 2, 5a-5b). Obviously, Chang Chien's suggestion was that the adoption of local assemblies was nothing else but a revival of old Chinese customs and traditions, and therefore it would not hurt Chinese dignity in adopting Japanese system of local assemblies.

After his return from Japan in 1903, Chang Chien's ideason local self-government was crystalized by the example of Japanese experience; During the period from 1906 to 1911, the thought that self-government was the basis of constitutional monarchy; During the period 1912 to 1914, he hoped that local self-government could be implemented under the republic; And thereafter until his death, he devoted himself to the cause of local self-government though it was neglected by the central government [11]. 


\section{The Content of Chang Chien's Thought on Local Self-Government}

The contents of Chang Chien's thought on local self-government can be summarized as the following: Local self-government under gentry in promoting industry, education and other local affairs as a means of saving China; Local self-government as the basis of constitutional monarchy; and Local elf-government as the basis of a republic.

\subsection{Local Self-Government under Gentry in Promoting Industry, Education and Other Local Affairs as a Means of Saving China}

The traditional Chinese gentry was a social group with a leading position and special privileges whist performing certain social functions. They undertook many tasks such as welfare activities, arbitration, public works, and at times the organization of local military corps or collection of taxes. Their cultural leadership encompassed all the value of Confucian society but was also materially expressed in such action as the preservation of village temples, schools, and examination halls [20].

However, Chang Chien believed that the most urgent reform to be adopted in China was industrialization. Since the rulers and officials failed to carry out necessary reforms as in the inadequate Self-Strengthening Movement of 1860-1894, Chang Chien urged the gentry to take over the work of China's economic modernization. Confronting the deep-seated tradition among the gentry that economic careers were beneath their dignity, Chang Chien took the contrary position argument "Only through industry, the gaining of wealth is right and honorable” [16] (Chiu-lu, Chiao Yu Lu, chuan 3, 20a).

Local self-government, according to Chang Chien, meant that everyone should devote himself to the development of industry, education, and other local affairs under the leadership of the intellectuals-the representatives of the people, and thus local councils were essential to self-government

\subsection{Local Self-Government as the Basis of Constitutional Monarchy}

Chang Chien saw local self-government as the basis of a constitutional monarchy. He expressed this point of view on different occasions, in 1906:

Local self-government is the essential basis of constitutional monarchy [16] (Chiu-lu, Cheng Wen Lu, chuan 3, 13a).

And in 1910, he praised the Ch'ing government's regulations for local self-government:

The Emperor has issued “The Regulations for the Local Self Government of Cities, Towns and Villages”. These regulations see local self-government as the root of constitutional monarchy, and see cities and villages as the primary foundation of local self-government [16] (Chiu-lu, Tzu Chi Lu, chuan 1, 11a).

And on 13 June, 1911, in Peking, Chang Chien told the Regent, Tsai-feng:

I have been paying particular attention to the affairs of local self-government since Emperor Kuang-hsu introduced the new reform of constitutional monarchy [15] (Jih-chi, 2676-2678).

Chang Chien always took a moderate, step by step, practical stand in the fulfillment of the affairs of selfgovernment and constitutional monarchy. He took action rather than empty rhetoric. He believed that the success of the reform movement depended on a function division and cooperation between the government and the gentry. The task for the government was to enforce a political reform, that is, to establish a constitutional government; the task for the gentry was to foster social reforms, including educational and economic modernization which he referred to "local self-government" [7]. In 1906, while his colleagues were arguing over the relative speed with which the constitutional movement should be pushed, he was willing to let the ultimate initiative come from the government. For private individuals, he believed, industry, education and local self-government should be the primary concern. He urged the government to inaugurate a constitutional regime and also advised the gentry to promote educational and economic modernization. He told them:

It is the responsibility of the government to establish a constitutional regime, and we the people should promote the local self-government by engaging ourselves in educational and economic careers. It is better to act than to talk. An advance from poverty and illiteracy to richness and literacy of even a foot or an inch is valuable [16] (Chiu-lu, Chuan Lu, chuan 7, 14b). 
Chang Chien was not a man equipped only with armchair strategies. He preferred to take action. This trait helped him in various enterprises in his home district, as well as in the promotion of local self-government and constitutional monarchy, He personally devoted himself to the development of industry, education and other affairs of local self-government in order to achieve a constitutional monarchy, and later a republic.

\subsection{Local Self-Government as the Basis of a Republic}

Although for a couple of years Chang Chien had been extraordinarily enthusiastic in the promotion of a constitutional monarchy, he changed from a constitutional monarchist to a republican within less than one month after the 1911 Revolution. Why did he change? The reasons leading to Chang Chien's change were complicated. However, the underlying reason could be attributed to his political thought with flexibility that industry, education and self-government which were able to be achieved under whether a constitutional monarchy or a republic [12].

After the establishment of the republic, Chang Chien still devoted himself to the cause of industry, education and other affairs of local self-government as the basis of a republic. Chang Chien said in 1915: The strengthening of the country is based on local self-government” [16] (Chiu-lu, Tzu Chih Lu, chuan 2, 9b); He said in 1920: "Local self-government is the imperative method to save the country from destruction" [16] (Chiu-lu, Tzu Chih Lu, chuan 3, 1a); And he said in 1918:

I did not like to be an official, and the context of Chinese politics did not allow me to fulfill my purpose as well. I wanted to achieve local self-government in my home district, so that the foreigners would recognize that China still had persons with great vision... In today, local self-government is the only way to save our country [16] (Chiu-lu, Chiao Yu Lu, chuan 4, 10a-10b).

In spite of his great concerns about the local self-government that would create the talents for the development of local and provincial affairs, Chang Chien was not interested in the so called Lien-sheng Tzu-chih (Federal Self-government) which arose around 1920-1924. In a letter to Hsu Fo-su, an advocate of Federal Self-government, Chang Chien said in 1921:

I think that unless each province can be governed well beforehand, federal self-government is impossible to be achieved [19].

And in a letter to Chao Yen-wu, the governor of Hunan Province, Chang Chien expressed his concern that he liked to see tangible achievements of local self-government rather than rhetoric of Federal Self-government [16] (Chiu-lu, Cheng Wen Lu, chuan 5, 13a-14a). Hence, Chang Chien was keen on local self-government, not on the so called Federal Self-government.

\section{Conclusions}

Chang Chien's thought on local self-government is closely related to his concerns on industry, education, and constitutional monarchy or later a republic. The main lines of Chang Chien's political thought may be summarized as follows: "industry is the basis of education; industry and education are the foundation of local selfgovernment; and local self-government is the basis of constitutional monarchy or later a republic” [11]. The contents of Chang Chien's thought on local self-government may be briefly summarized as the following: 1) Local self-government under gentry in promoting industry, education and other local affairs as a means of saving China; 2) Local government as the basis of constitutional monarchy; and 3) Local self-government as the basis of a republic.

Chang Chien's thought on local self-government pays emphasis on carrying out industry, education and other local affairs under the leadership of the gentry. Chang Chien sees Local self-government can be achieved under whether a constitutional monarchy or a republic in order to save China.

With the pragmatic and reciprocal aspects of Confucian ideas serving the people, adjusting to China's concrete situations, Chang Chien developed his thought: firstly, saving China by industry from 1866; secondly, saving China by industry and education from 1895 to 1900; thirdly saving China by industry, education and selfgovernment from 1900 to 1903; fourthly saving China by industry, education, self-government under a constitutional monarchy from 1903 to 1911; and lastly, saving China by industry, education, self-government under a republic from one month after 1911 Revolution until his death in 1926. Chang Chien personally had devoted to 
the cause of industry, education and other affairs of local self-government, and he had made great contributions to China's modernization.

\section{References}

[1] Chang, H.-J. (1930) Nant'ung Chang Chi-chihHsien-sheng Chuan-chi (Biography of Mr. Chang Chien of Nant'ung). Chung Hua Bookstore, Shanghai.

[2] Sung, H.-S. (1963) Chang Chiente Shengp'ing (The Career of Chang Chien). Chinese Books Compilation Commission, Taipei.

[3] Liu, H.-S. (1958) Chang Chien Chuan-chi (Biography of Chang Chien). Lung Men Joint Bookstore, Shanghai.

[4] Chu, S.C. (1965) Reformer in Modern China: Chang Chien, 1853-1926. Columbia University Press, New York and London.

[5] Chang, K.-Y. (2000) Chang Chien Chuan (The Biography of Chang Chien). China Industry and Commerce Associated Press, Beijing.

[6] Wang, T.-C. (2005) Ch'uang-t’ungyu Ch'ian-chan: Chang Chien Ching-chi Ssi-hsiang Yen-chiu (Tradition and Perspective: A Research on Chang Chien's Economic Thought). People's Press, Beijing.

[7] Wong, K.-K. (1957) Chang Chien: A Case Study of Attempts at China's Modernizationby the Traditional Gentry. Unpublished Master Thesis, University of Washington, Seattle.

[8] Lee, M. (1966) The Development of Exalt Commerce in Late Ch'ing Thought. Unpublished Ph.D. Thesis, The University of Sydney, Sydney.

[9] Chang, P.-Y. (1968) The Constitutionalists. In: Wright, M.C., Ed., China in Revolution: The First Phase 1900-1913, Yale University Press, New Heaven and London, 143-183.

[10] Koll, E. (2003) From Cotton Mill to Business Empire: The Emergence of Regional Enterprises in Modern China. Harvard University Asia Center, Cambridge, MA.

[11] Sun, S.-C. (1991) Chang Chien (1853-1926): Political Thought and Action. Ph.D. Thesis, University of New South Wales, Sydney; Shi-Ying Publisher, Taipei.

[12] Sun, S.-C. (2013) On Chang Chien's Change from a Constitutional Monarchist to a Republican—Political Thought with Flexibility as the Underlying Reason. Global Journal of Human Social Science Political Science, 1, 1-15.

[13] Chang Chien International Symposium Committee (2007) Chang Chienyu Chin-tai Chung-kuo She-hui-Ti ssu-chieh Chang ChienKuo-chi Hsuehshu Yen-t’ao-huiLun-wen-chi (Chang Chien and Chinese Society-The Fourth International Symposium on Chang Chien). Nanking University Press, Nanking.

[14] Ts'ui, C.-C., et al. (2010) Chang ChienyuHaimen: Tsao-ch'iHsien-tai-huaSsu-hsiangyu Shih-Chien (Chang Chien and Haimen: The Thoughts and Practice in the Early Period of Modernization). Nanking University Press, Nanking.

[15] Chang, C. (1986). Liu-his-ts'ao-t’angJih-chi (Chang Chien’s Diary). Wen Hai Press, Taipei.

[16] Chang, H.-J. (1983) Chang-chi-tzu Chiu-lu (The Nine Records of Chang Chien). Wen Hai Press, Taipei.

[17] Chang Chien Research Center (1994) Chang ChienCh’uan-chi (The Complete Work of Chang Chien). Kiangsu Classic Books Press, Kiangsu.

[18] Li, M.-H. and Yu, S.-W. (2012) Chang ChienCh’uan-chi (The Complete Work of Chang Chien). Shanghai Dictionary and Books Press, Shanghai.

[19] Yang, L.-C., Shen, W.-P., et al. (1987) Chang ChienTs'un-kao (Extant Writings of Chang Chien). People’s Press, Shanghai, 332.

[20] Chang, C.-L. (1955) The Chinese Gentry: Studies on Their Role in Nineteenth Century Chinese Society. University of Washington Press, Seattle, 197-198. 